\title{
A primeira revolução do século XXI? Bolivarianis- mo e socialismo na Venezuela
}

\author{
Raphael Lana Seabra \\ Orientador: Sadi Dal Rosso \\ Tese de Doutorado \\ Data da defesa: 04.04.2012
}

\begin{abstract}
A presente tese tem como objetivo central determinar se a República Bolivariana da Venezuela atravessa, de fato, por uma revolução, que, devido às perspectivas de renovação da esquerda marxista, da importância da ruptura revolucionária e da transição ao socialismo para a região, lançamos tal problema como a primeira revolução do século XXI. Ao longo da tese, buscamos definir os conceitos fundamentais da Revolução Bolivariana, tais como bolivarianismo, chavismo, democracia participativa e protagônico e o socialismo do século XXI - todos representam eixos indispensáveis à compreensão do projeto de fundação da Quinta República. Realizamos longo trabalho de campo e entrevistas com intelectuais, militantes e membros do governo bolivariano. Estabelecemos uma contribuição à periodização do processo revolucionário bolivariano em três etapas: a etapa constituinte, a etapa nacional-soberana e a etapa da via venezuelana ao socialismo. Como processo revolucionário, cuja especificidade reside na conquista gradual e pacífica do poder político, sem postular a ruptura imediata com a ordem capitalista, seguindo a via legítima de radicalização democrática, até a criação de um sistema múltiplo de propriedade (as propriedades estatal, social e privada), com vistas a superar, em médio e longo prazo, as bases da dominação imperialista, latifundiária e monopolista, através da consolidação permanente de tais transformações, consideramos tais etapas não em sentido estancado e evolucionista, senão, como processo de revolução permanente que segue em alternâncias entre rupturas e períodos mais ou menos radicais dentro sua própria dinâmica. Concluímos que o processo, ao avançar, de forma "redistributiva", da renda petroleira entre as classes subalternas, tende, indiretamente, a reforçar o regime de acumulação de determinadas frações capitalistas, fato que poderia levar a revolução à sua interrupção.
\end{abstract}

Palavras-chave: Revolução, Democracia, Bolivarianismo, Chavismo, Socialismo. 